\title{
MODEL PEMBELAJARAN KOOPERATIF PERSPEKTIF AL-QUR'AN
}

\author{
Ismail Marzuki \\ Lukamanul Hakim \\ Ismail_mz3@yahoo.co.id \\ (Dosen Fakultas Agama Islam Universitas Muhammadiyah Tangerang)
}

\begin{abstract}
Abstrak:
Model pembelajaran kooperatif mampu meningkatkan efektivitas pembelajaran, mengutamakan kerjasama antar siswa untuk mencapai tujuan pembelajaran, mengubah peran guru, dari yang berpusat pada gurunya ke pengelolaan siswa dalam kelompokkelompok kecil, digunakan untuk mengajarkan materi yang kompleks, membantu guru untuk mencapai tujuan pembelajaran yang berdimensi sosial, memberikan kesempatan kepada siswa untuk lebih mengembangkan kemampuan, dan siswa dituntut untuk aktif dalam belajar melalui kegiatan kerjasama kelompok.
\end{abstract}

\section{Kata Kunci: Model pembelajaran kooperatif, al-qu’an.}

\section{A. Pendahuluan}

Adanya kecenderungan sekolahsekolah membentuk kelas-kelas unggulan atas dasar prestasi akademik dewasa ini disinyalir patut dikaji ulang. Apakah kecenderungan itu didasari atas pertimbangan yang sejalan dengan tujuan pendidikan kita ataukah karena pertimbangan lain sesuai dengan permintaan pasar yang bersifat sesaat. Sistem persekolahan yang ada sekarang ini cenderung memperlakukan siswa secara kurang adil dan kurang humanistis. Siswa pandai diberi label unggul dengan segala fasilitas yang diberikannya, sementara siswa yang di kelas tak unggul memperoleh label kurang dan predikat negatif yang lain. Siswa pada kelompok unggul berkompetisi secara keras dan cenderung individualistik. Sementara siswa di kelas tidak unggul merasa tidak mampu, frustasi dan selanjutnya menerima keadaan itu.

Persoalan lain yang menunjukan aspek kompetitif dan individualistik dalam pendidikan kita adalah model pembelajaran langsung (model pembelajaran konvensional). Pada pembelajaran konvensional, guru menjadi pusat pembelajaran, berperan mentransfer dan meneruskan (transmit) informasi sehingga siswa tidak perlu mengkonstruksi ide-idenya. Tingkat partisipasi siswa sangat terbatas karena arus interaksi didominasi oleh guru. Bentuk penugasan dalam pembelajaran ini bersifat individual. Sebagai konsekuensinya, evaluasi yang diterapkan dikelaspun juga individual.

Dalam hal ini, guru perlu menyusun dan melaksanakan kegiatan belajar mengajar dimana siswa dapat aktif membangun pengetahuannya sendiri. Hal ini sesuai dengan pandangan kontruktivisme yaitu keberhasilan belajar tidak hanya bergantung pada lingkungan atau kondisi belajar, tetapi juga pada pengetahuan awal siswa. Keberhasilan dalam proses pembelajaran dipengaruhi oleh dua faktor yaitu faktor internal dan faktor eksternal. Faktor internal yaitu faktor yang berkaitan dengan diri siswa, diantaranya adalah kemampuan, minat, motivasi, keaktifan belajar dan lain-lain. Sedangkan faktor eksternal adalah faktor dari luar diri siswa, diantaranya adalah model pembelajaran. 


\section{B. Model Pembelajaran}

Model pembelajaran dikembangkan dari adanya perbedaan karakteristik siswa yang bervariasi. Karena siswa memiliki berbagai karakteristik kepribadian, kebiasaan-kebiasaan, cara belajar yang bervariasi antara individu satu dengan yang lain, maka model pembelajaran tidak terpaku hanya pada model tertentu. Menurut Agus Suprijono ${ }^{1}$ model pembelajaran merupakan landasan praktik pembelajaran hasil penurunan teori psikologi pendidikan dan teori belajar yang dirancang berdasarkan analisis terhadap implementasi kurikulum dan implikasinya pada tingkat operasional di kelas. Model pembelajaran dapat diartikan pula sebagai pola yang digunakan untuk penyusunan kurikulum, mengatur materi dan memberi petunjuk kepada guru di kelas.

Selanjutnya menurut Arends dalam Suprijono $^{2}$ model pembelajaran ialah pola yang digunakan sebagai pedoman dalam merencanakan pembelajaran di kelas maupun tutorial. Model pembelajaran mengacu pada pendekatan yang akan digunakan, termasuk di dalamnya tujuantujuan pembelajaran, tahap-tahap dalam kegiatan pembelajaran, lingkungan pembelajaran, dan pengelolaan kelas. Menurut Joyce \& Weil dalam Rusman ${ }^{3}$ berpendapat bahwa model pembelajaran adalah suatu rencana atau pola yang dapat digunakan untuk membentuk kurikulum (rencana pembelajaran jangka panjang), merancang bahan-bahan pelajaran dan membimbing pelajaran di kelas atau yang lain.

${ }^{1}$ Agus Suprijono. (2014). Cooperative Learning: Teori dan Aplikasi PAIKEM. Yogyakarta: Pustaka Pelajar. Hal. 45-46.

${ }^{2}$ Agus Suprijono. (2014). Cooperative Learning: Teori dan Aplikasi PAIKEM. Yogyakarta: Pustaka Pelajar. Hal. 46.

${ }^{3}$ Rusman. (2012). Model-model Pembelajaran. Jakarta: PT. Raja Grafindo Persada. Hal. 133.
Kemudian menurut Soekamto dalam Trianto, ${ }^{4}$ model pembelajaran adalah kerangka konseptual yang melukiskan prosedur yang sistematis dalam mengorganisasikan pengalaman belajar untuk mencapai tujuan belajar tertentu, dan berfungsi sebagai pedoman bagi para perancang pembelajaran dan para pengajar dalam merencanakan aktivitas belajar mengajar. Berdasarkan pendapat di atas dapat dinyatakan bahwa model pembelajaran adalah kerangka konseptual yang melukiskan pola atau prosedur secara sistematis dalam mengorganisasikan pembelajaran yang berfungsi sebagai pedoman bagi para pengajar dalam merencanakan dan melaksanakan pembelajaran.

Menurut Nieveen dalam Trianto, ${ }^{5}$ suatu model pembelajaran dapat dikatakan baik jika memenuhi kriteria sebagai berikut:

1. Sahih (valid), aspek validitas dikaitkan dengan dua hal, yaitu:

a. Apakah model yang dikembangkan didasarkan pada rasional teoritis yang kuat

b. Apakah terdapat konsistensi internal

2. Praktis, aspek kepraktisannya hanya dapat dipenuhi jika:

a. Para ahli dan praktisi menyatakan bahwa apa yang dikembangkan dapat diterapkan

b. Kenyataan menunjukkan bahwa apa yang dikembangkan tersebut dapat diterapkan

3. Efektif, berkaitan dengan efektifitas ini, Nieveen memberikan parameter sebagai berikut:

${ }^{4}$ Trianto. (2007) Model-model Pembelajaran Inovatif Berorientasi Konstruktivistik. Jakarta: Prestasi Pustaka. Hal. 22.

${ }^{5}$ Trianto. (2007) Model-model Pembelajaran Inovatif Berorientasi Konstruktivistik. Jakarta: Prestasi Pustaka. Hal.25. 
a. Ahli dan praktisi berdasarkan pengalamannya menyatakan bahwa model tersebut efektif

b. Secara oprasional model tersebut memberikan hasil sesuai dengan yang diharapkan

Dalam mengajarkan suatu pokok bahasan atau materi tertentu harus dipilih model pembelajaran yang paling sesuai dengan tujuan yang akan dicapai. Oleh karena itu, dalam memilih suatu model pembelajaran harus memiliki pertimbangan-pertimbangan. Misalnya materi pelajaran, tingkat perkembangan kognitif siswa dan sarana atau fasilitas yang tersedia, sehingga tujuan pembelajaran yang telah ditetapkan dapat tercapai.

\section{Jenis-Jenis Model Pembelajaran}

Model pembelajaran merupakan langkah awal yang harus direncanakan di dalam proses belajar mengajar secara keseluruhan. Beberapa model pembelajaran menurut Peraturan Menteri Pendidikan dan Kebudayaan Republik Indonesia, Nomor: 49 Tahun 2014 tentang Standar Nasional Pendidikan Tinggi, Pasal 14 adalah sebagai berikut: Small Group Discussion, Simulation, Case Study, Discovery Learning (DL), Self Directed Learning (SDL), Cooperative Learning (CL), Collaborative Learning (CbL), Contextual Instruction (CI), Project Based Learning (PjBL) dan Problem Based Learning and Inquiry (PBL/I). ${ }^{6}$ MetodeMetode pada Student Centered Learning, antara lain:

1. Small Group Discussion. Diskusi merupakan salah satu elemen belajar secara aktif dan merupakan bagian dari banyak model pembelajaran SCL yang

${ }^{6}$ Peraturan Menteri Pendidikan Dan Kebudayaan Republik Indonesia, Nomor 49 Tahun 2014 Tentang Standar Nasional Pendidikan Tinggi, Pasal 14. lain, seperti: CL, CBL, PBL dan lainlain. Di dalam kelas, kita dapat meminta para mahasiswa untuk membuat kelompok kecil (misalnya 510 orang) untuk mendikusikan bahan yang dapat diberikan oleh pengajar ataupun bahan yang diperoleh sendiri oleh anggota kelompok tersebut. Metode ini dapat digunakan ketika akan menggali ide, menyimpulkan poin penting, mengakses tingkat skill dan pengetahuan mahasiswa, mengkaji kembali topik di kelas sebelumnya, membandingkan teori, isu dan interprestasi, dapat juga untuk menyelesaikan masalah. Apa bisa dilakukan oleh mahasiswa, ketika metode ini diterapkan di kelas. Mahasiswa akan belajar untuk menjadi pendengar yang baik, bekerjasama untuk tugas bersama, memberikan dan menerima umpan balik yang konstruktif, menghormati perbedaan pendapat, mendukung pendapat dengan bukti, serta menghargai sudut pandang yang bervariasi.

2. Simulation. Simulasi adalah model yang membawa situasi yang mirip dengan sesungguhnya ke dalam kelas. Misalnya simulasi sebagai seorang manajer atau pemimpin, mahasiswa diminta untuk membuat perusahaan fiktif, kemudian di minta untuk berperan sebagai manajer atau pemimpin dalam perusahaan tersebut. Simulasi ini dapat berbentuk permainan peran (role playing). Permainan-permainan simulasi dan lain-lain. manfaat dari model ini adalah dapat mengubah cara pandang (mindset) mahasiswa dengan cara mempraktekkan kemampuan umum (dalam komunikasi verbal dan nonverbal), mempraktekkan kemampuan khusus mempraktekkan kemampuan tim, mengembangkan kemampuan menyelesaikan masalah, 
mengembangkan kemampuan empati dan lain-lain.

3. Discovery Learning (DL). DL adalah metode belajar yang difokuskan pada pemanfaatan informasi yang tersedia, baik yang diberikan pengajar maupun yang dicari sendiri oleh mahasiswa, untuk membangun pengetahuan dengan cara belajar mandiri. Metode ini dapat dilakukan misalnya dengan memberikan tugas kepada mahasiswa untuk memperoleh bahan ajar dari sumber-sumber yang dapat diperoleh melalui internet atau melalui buku, koran, majalah dan lain sebagainya.

4. Self Directed Learning (SDL). SDL adalah proses belajar yang dilakukan atas inisiatif individu mahasiswa sendiri. Mahasiswa sendiri yang merencanakan, melaksanakan dan menilai sendiri terhadap pengalaman belajar yang telah dijalani, dilakukan semuanya oleh individu yang bersangkutan. Peran pengajar dalam metode ini hanya bertindak sebagai fasilitator, yang memberi arahan, bimbingan dan konfirmasi terhadap kemajuan belajar yang telah dilakukan individu mahasiswa tersebut. Manfaat dari metode ini adalah menyadarkan dan memberdayakan mahasiswa, bahwa belajar adalah tanggung jawab mereka sendiri. Individu mahasiswa didorong untuk bertanggung jawab terhadap semua fikiran dan tindakan yang dilakukannya. Untuk dapat menerapkan metode ini, sebelumnya kita harus dapat memenuhi asumsi bahwa kemampuan mahasiswa semestinya bergeser dari orang yang tergantung pada orang lain menjadi individu yang mampu belajar mandiri.

5. Cooperative Learning (CL). CL merupakan metode belajar berkelompok yang dirancang oleh pengajar untuk memecahkan suatu masalah/kasus atau mengerjakan suatu tugas. Kelompok ini terdiri dari atas beberapa orang mahasiswa yang memiliki kemampuan akademik yang beragam. Metode ini sangat terstruktur, karena pembentukan kelompok, materi yang dibahas, langkah-langkah diskusi serta produk akhir yang harus dihasilkan, semuanya ditentukan dan dikontrol oleh pengajar. Mahasiswa hanya mengikuti prosedur diskusi yang dirancang oleh Pengajar. CL bermanfaat untuk membantu menumbuhkan dan mengasah kebiasaan belajar aktif pada diri mahasiswa, rasa tanggungjawab individu dan kelompok mahasiswa, kemampuan dan ketrampilan bekerjasama antar mahasiswa, dan keterampilan sosial mahasiswa.

6. Collaborative Learning (CbL). CbL adalah metode belajar yang menitikberatkan pada kerja sama antar mahasiswa yang didasarkan pada konsensus yang dibangun sendiri oleh anggota kelompok. Masalah/tugas/ kasus memang berasal dari pengajar dan bersifat open ended, tetapi pembentukan kelompok yang didasarkan pada minat, prosedur kerja kelompok, penentuan waktu dan tempat diskusi/kerja kelompok, sampai dengan bagaimana hasil diskusi/kerja kelompok ingin dinilai oleh pengajar, semuanya ditentukan melalui Konsensus bersama antar anggota kelompok.

7. Contextual Instruction (CI). CI adalah konsep belajar yang membantu pengajar mengaitkan isi mata kuliah dengan situasi nyata dalam kehidupan sehari-hari dan memotivasi mahasiswa untuk membuat keterhubungan antara pengetahuan dan aplikasinya dalam kehidupan sehari-hari sebagai anggota masyarakat, pelaku kerja professional atau manajerial, entrepreneur, maupun investor. Contoh: apabila kompetensi 
yang dituntut matakuliah adalah mahasiswa dapat menganalisis faktorfaktor yang mempengaruhi proses transaksi jual beli, maka dalam pembelajarannya, selain konsep transaksi ini dibahas dalam kelas, juga diberikan contoh dan mendiskusikannya. Mahasiswa juga diberi tugas dan kesempatan untuk terjun langsung di pusat-pusat perdagangan untuk mengamati secara langsung proses transaksi jual beli tersebut, atau bahkan terlibat langsung sebagai salah satu pelakunya, sebagai pembeli misalnya.

8. Project-based Learning (PjBL). PjBL adalah metode belajar yang sistematis, yang melibatkan mahasiswa dalam belajar pengetahuan dan ketrampilan melalui proses pencarian/penggalian (inquiry) yang panjang dan terstruktur terhadap pertanyaan yang otentik dan kompleks serta tugas dan produk yang dirancang dengan sangat hati-hati.

9. Problem-based Learning/Inquiry (PBL/I). PBL/I adalah belajar dengan memanfaatkan masalahan mahasiswa harus melakukan pencarian/penggalian informasi (inquiry) untuk dapat memecahkan masalah tersebut. Pada umumnya, terdapat empat langkah yang perlu dilakukan mahasiswa dalam PBL/I, yaitu:

a. Menerima masalah yang relevan dengan salah satu/beberapa kompetensi yang dituntut mata kuliah, dari pengajarnya.

b. Melakukan pencarian data dan infromasi yang relevan untuk memecahkan masalah.

c. Menata data dan mengaitkan data dengan masalah

d. Menganalisis strategi pemecahan masalah.

Jenis-jenis model pembelajaran yang diuraikan di atas, tidak ada model pembelajaran yang paling baik, karena setiap model pembelajaran memiliki kelebihan dan kekurangan. Pemilihan model pembelajaran harus disesuaikan dengan rumusan tujuan pembelajaranyang telah ditetapkan, analisis kebutuhan dan karakteristik peserta didik yang dihasilkan dan jenis materi yang akan diajarkan.

\section{Pembelajaran Kooperatif}

1. Pengertian Pembelajaran Kooperatif Pembelajaran kooperatif (cooperatif learning) merupakan bentuk pembelajaran dengan cara siswa belajar dan bekerja dalam kelompok-kelompok kecil secara kolaboratif yang anggotanya terdiri dari empat sampai dengan enam orang dengan struktur kelompok yang bersifat heterogen. ${ }^{7}$ Menurut Tom V. Savage sebagaimana dikutip oleh Rusman ${ }^{8}$, pembelajaran kooperatif yaitu: Suatu pendekatan yang menekankan kerjasama dalam kelompok. Dalam pembelajaran kooperatif proses pembelajaran tidak harus belajar dari guru kepada siswa. Siswa juga dapat saling membelajarkan sesama siswa lainnya. Pembelajaran oleh rekan sebaya (peerteaching) lebih efektif daripada pembelajaran oleh guru.

Menurut Robert E. Slavin ${ }^{9}$ metode pembelajaran kooperatif, para siswa akan duduk bersama dalam kelompok yang beranggotakan empat orang untuk menguasai materi yang disampaikan oleh guru.

\section{Tujuan Pembelajaran Kooperatif}

Nur Asma mengemukakan bahwa pengembangan pembelajaran kooperatif

${ }^{7}$ Rusman. (2012). Model-model Pembelajaran. Jakarta: PT. Raja Grafindo Persada. Hal. 202.

${ }^{8}$ Rusman. (2012). Model-model Pembelajaran. Jakarta: PT. Raja Grafindo Persada. Hal. 203.

${ }^{9}$ Slavin, Robert. E. (2009). Cooperative Learning Teori, Riset, \&Praktik. Bandung: Nusa Media. Hal. 8. 
memiliki beberapa tujuan ${ }^{10}$, yaitu:

a. Pencapaian Hasil Belajar. Meskipun pembelajaran kooperatif meliputi berbagai macam tujuan sosial, pembelajaran kooperatif juga bertujuan untuk meningkatkan kinerja siswa dalam tugas-tugas akademik. Pembelajaran kooperatif dapat memberi keuntungan pada siswa dalam tugas-tugas akademik, baik kelompok bawah maupun kelompok atas. Siswa kelompok atas akan menjadi tutor bagi siswa kelompok bawah. Dalam proses tutorial ini, siswa kelompok atas akan meningkat kemampuan akademiknya karena memberi pelayanan sebagai tutor kepada teman sebaya yang membutuhkan pemikiran lebih mendalam tentang hubungan ide-ide yang terdapat di dalam materi tertentu.

b. Penerimaan Terhadap Perbedaan Individu. Efek penting kedua dari model pembelajaran kooperatif ialah penerimaan yang luas terhadap orang yang berbeda menurut ras, budaya, tingkat sosial, kemampuan maupun ketidakmampuan. Pembelajaran kooperatif memberikan peluang kepada siswa yang berbeda latar belakang dan kondisi untuk bekerja saling bergantung satu sama lain atas tugastugas bersama, dan melalui penggunaan struktur penghargaan kooperatif, serta belajar untuk menghargai satu sama lain.

c. Pengembangan Keterampilan Sosial. Tujuan Penting ketiga dari pembelajaran kooperatif ialah untuk mengajarkan kepada siswa keterampilan kerja sama dan kolaborasi. Keterampilan ini amat penting untuk dimiliki di dalam

\footnotetext{
${ }^{10}$ Nur Asma. (2006). Pendekatan Pembelajaran Kooperatif. Jakarta: Departemen Pendidikan Nasional Direktorat Jenderal Pendidikan Tinggi Direktorat Ketenagaan. Hal.12.
}

masyarakat, banyak kerja orang dewasa dilakukan dalam organisasi yang saling bergantung satu sama lain dalam masyarakat, meskipun beragam budayanya.

\section{Prinsip Pembelajaran Kooperatif.}

Menurut Nur Asma pelaksanaam pembelajaran kooperatif setidaknya terdapat lima prinsip yang dianut yaitu: ${ }^{11}$

a. Belajar Siswa Aktif (Student Active Learning). Proses pembelajaran dengan menggunakan model kooperatif berpusat pada siswa, aktivitas belajar lebih dominan dilakukan siswa, pengetahuan yang dibangun dan ditemukan adalah dengan belajar bersama-sama dengan anggota kelompok sampai masing-masing siswa memahami materi pembelajaran dan mengakhiri dengan membuat laporan kelompok dan individual.

b. Belajar Kerjasama (Cooperative Learning). Seluruh siswa terlibat secara aktif dalam kelompok untuk melakukan diskusi, memecahkan masalah dan mengujinya secara bersama-sama, sehingga terbentuk pengetahuan baru dari hasil kerjasama mereka. Diyakini yang diperoleh melalui penemuan-penemuan dari hasil kerjasama ini akan lebih baik permanen dalam pemahaman masing-masing siswa.

c. Pembelajaran Partisipatorik. Melalui model pembelajaran ini siswa belajar dengan melakukan sesuatu (learning by doing) secara bersama-sama untuk menemukan dan membangun pengetahuan yang menjadi tujuan pembelajaran.

\footnotetext{
${ }^{11}$ Nur Asma. (2006). Pendekatan Pembelajaran Kooperatif. Jakarta: Departemen Pendidikan Nasional Direktorat Jenderal Pendidikan Tinggi Direktorat Ketenagaan. Hal. 1416.
} 
d. Mengajar Reaktif (Reactive Teaching). Untuk menerapkan model pembelajaran kooperatif ini, guru perlu menciptakan strategi yang tepat agar seluruh siswa mempunyai motivasi belajar yang tinggi. Motivasi siswa dapat dibangkitkan jika guru mampu menciptakan suasana belajar yang menyenangkan dan menarik serta dapat meyakinkan siswanya akan manfaat pelajaran ini untuk masa depan mereka.

e. Pembelajaran yang Menyenangkan (Joyfull Learning). Model pembelajaran kooperatif menganut prinsip pembelajaran yang menyenangkan. Suasana belajar yang menyenangkan harus dimulai dari sikap dan perilaku guru di luar maupun dalam kelas. Guru harus memilki sikap yang ramah dengan tutur bahasa yang menyayangi siswa-siswanya.

\section{Unsur-unsur Penting dalam Pembelajaran Kooperatif}

Menurut Johnson \& Johnson sebagaimana dikutip oleh Rusman ${ }^{12}$ terdapat lima unsur penting dalam belajar kooperatif, yaitu:

a. Saling ketergantungan yang bersifat positif antara siswa. Dalam belajar kooperatif siswa merasa bahwa mereka sedang bekerja sama untuk mencapai satu tujuan dan terikat satu sama lain. Seorang siswa tidak akan sukses kecuali semua anggota kelompoknya juga sukses. Siswa akan merasa bahwa dirinya merupakan bagian dari kelompok yang juga mempunyai andil terhadap suksesnya kelompok.

b. Interaksi antara siswa yang semakin meningkat. Belajar kooperatif akan meningkatkan interaksi antara siswa. Hal ini, terjadi dalam hal seorang siswa akan membantu siswa lain untuk sukses sebagai anggota kelompok.

\section{${ }^{12}$ Rusman. (2012). Model-model} Pembelajaran. Jakarta: PT. Raja Grafindo Persada. Hlm. 159.
Saling memberikan bantuan ini akan berlangsung secara alamiah karena kegagalan seseorang dalam kelompok mempengaruhi suksesnya kelompok. Untuk mengatasi masalah ini, siswa yang membutuhkan bantuan akan mendapatkan dari teman sekelompoknya. Interaksi yang terjadi dalam belajar kooperatif adalah dalam hal tukar menukar ide mengenai masalah yang sedang dipelajari bersama.

c. Tanggung jawab individual. Tanggung jawab individual dalam belajar kelompok dapat berupa tanggung jawab siswa dalam hal membantu siswa yang membutuhkan bantuan dan siswa tidak dapat hanya sekedar "membonceng" pada hasil kerja teman sekelompoknya.

d. Keterampilan interpersonal dan kelompok kecil. Dalam belajar kooperatif, selain dituntut untuk mempelajari materi yang diberikan seorang siswa dituntut untuk belajar bagaimana berinteraksi dengan siswa lain dalam kelompoknya. Bagaimana siswa bersikap sebagai anggota kelompok dan menyampaikan ide dalam kelompok akan menuntut keterampilan khusus.

e. Proses kelompok. Belajar kooperatif tidak akan berlangsung tanpa proses kelompok. Proses kelompok terjadi jika anggota kelompok mendiskusikan bagaimana mereka akan mencapai tujuan dengan baik dan membuat hubungan kerja yang baik.

\section{Langkah-langkah dalam Pembelajaran Kooperatif}

Dalam rangka pengelolaan kelas di dalam pembelajaran kooperatif seorang pengajar dituntut mengarahkan dan membina para siswa untuk mengembangkan minat dan kiat bekerjasama dalam berinteraksi dengan pembelajar lainnya. Ada beberapa hal yang 
perlu diperhatikan seorang pengajar, ${ }^{13}$ yaitu:

a. Pengelompokan. Dalam rangka pengelompokan atau membentuk kelompok maka yang perlu diperhatikan adalah heterogenitas dari anggota kelompok, seperti keanekaragaman latar belakang sosioekonomi, etnik, dan kemampuan akademis. Dalam hal kemampuan akademis, dalam satu kelompok diharapkan ada yang berkemampuan tinggi, sedang dan rendah. Adapun manfaat dari pengelompokan secara heterogenitas adalah:

1) Memberi kesempatan untuk saling berbagi sesama teman dan saling mendukung.

2) Meningkatkan relasi dan interaksi antar siswa.

3) Memudahkan dan meringankan tugas guru dalam mengajar.

b. Semangat kerjasama. Agar proses pembelajaran kooperatif berjalan efektif maka perlu adanya pembinaan dan niat kerjasama. Oleh karena itu guru perlu untuk selalu memberikan pembinaan akan pentingnya arti kerjasama, sehingga setiap siswa mempunyai semangat kerjasama yang tinggi dalam belajar.

c. Penataan ruang kelas. Dalam pembelajaran kooperatif penataan ruang kelas merupakan suatu hal yang sangat penting dalam menunjang keberhasilan belajar para siswa. Dalam penataan ruang kelas ada beberapa hal yang perlu untuk diperhatikan yaitu: ukuran ruang kelas, jumlah siswa, tingkat kedewasaan siswa, toleransi guru dan kelas sebelah terhadap kegaduhan dan lalu lalang siswa, toleransi masing-masing siswa terhadap kegaduhan dan lalu lalang siswa lain, pengalaman guru dalam

${ }^{13}$ Anita Lie. (2003). Cooperative Learning: Mempraktekkan Coopeartif Learning di Ruangruang Kelas. Jakarta: PT Grasindo. Hlm. 38. melaksanakan metode pembelajaran kooperatif, dan pengalaman siswa dalam melaksanakan model pembelajaran kooperatif.

Adapun penataan bangku siswa yang dapat dijadikan pilihan oleh para guru yang hendak melaksanakan pembelajaran kooperatif, ${ }^{14}$ yaitu:

a. Meja tapal kuda: siswa berkelompok diujung meja

b. Meja panjang: siswa berkelompok diujung meja

c. Penataan tapal kuda: siswa dalam satu kelompok ditempatkan berdekatan

d. Meja laboratorium

e. Meja kelompok: siswa dalam satu kelompok ditempatkan berdekatan

f. Klasifikal: siswa dalam satu kelompok ditempatkan berdekatan

g. Meja berbaris: dua kelompok duduk berbagi satu meja

\section{E. Macam-Macam \\ Kooperatif}

Pembelajaran

Menurut Robert E.Slavin, ${ }^{15}$ berbagai metode pembelajaran kooperatif adalah sebagai berikut:

\section{Pembelajaran Tim Siswa}

Metode Student Team Learning (Pembelajaran Tim Siswa) adalah teknik pembelajaran kooperatif yang dikembangkan dan diteliti oleh John Hopkins University. Lebih dari separuh dari semua kajian praktis tentang metode pembelajaran kooperatif menerapkan metode ini. Semua metode pembelajaran kooperatif menyumbangkan ide bahwa siswa yang bekerja sama dalam belajar dan bertanggung jawab terhadap teman satu timnya mampu membuat diri mereka belajar sama baiknya. Sebagai tambahan terhadap gagasan tentang kerja kooperatif, metode PTS menekankan penggunaan

${ }^{14}$ Anita Lie. (2003). Cooperative Learning: Mempraktekkan Coopeartif Learning di Ruangruang Kelas. Jakarta: PT Grasindo. Hlm. 51.

${ }^{15}$ Slavin,Robert.E. (2009). Cooperative Learning Teori, Riset, \& Praktik. Bandung: Nusa Media. Hlm. 10. 
tujuan-tujuan tim dan sukses tim, yang hanya akan dapat dicapai apabila semua anggota tim bisa belajar mengenai pokok bahasan yang telah diajarkan. Oleh sebab itu, dalam metode PTS tugas-tugas yang diberikan pada siswa bukan melakukan sesuatu sebagai sebuah tim, tetapi belajar sesuatu sebagai sebuah tim. Tiga konsep bagi semua metode PTS penghargaan bagi tim, tanggung jawab individu, dan kesempatan sukses yang sama. Tim akan mendapatkan sertifikat, atau penghargaanpenghargaan tim lainnya jika mereka berhasil melampaui kriteria tertentu yang telah ditetapkan. Tim tidak bersaing untuk mendapatkan penghargaan yang tidak mungkin; semua (atau tidak ada) anggota tim yang bisa saja ada yang mencapai kriteria pada minggu tersebut. Tanggung jawab individual maksudnya adalah bahwa kesuksesan tim bergantung pada pembelajaran individu dari semua anggota tim. Tanggung jawab difokuskan pada kegiatan anggota tim dalam membantu satu sama lain untuk belajar dan memastikan bahwa tiap orang dalam tim siap untuk mengerjakan kuis atau bentuk penilaian lainnya yang dilakukan siswa tanpa bantuan teman satu timnya. Kesempatan sukses yang sama maksudnya, bahwa semua siswa memberi kontribusi kepada timnya dengan cara meningkatkan kinerja mereka dari yang sebelumnya. Ini akan memastikan bahwa siswa dengan prestasi tinggi, sedang dan rendah semuanya samasama ditantang untuk melakukan yang terbaik, dan bahwa kontribusi dari semua anggota tim ada nilainya.

\section{Student Team-Achievement Division (STAD)}

Dalam STAD, para siswa dibagi dalam tim belajar yang terdiri atas empat orang yang berbeda-beda tingkat kemampuan, jenis kelamin, dan latar belakang etniknya. Guru menyampaikan pelajaran, lalu siswa bekerja dalam tim mereka untuk memastikan bahwa semua anggota tim telah menguasai pelajaran.
Selanjutnya, semua siswa mengerjakan kuis mengenai materi secara sendirisendiri, di mana saat itu mereka tidak diperbolehkan untuk saling bantu. Skor kuis para siswa dibandingkan dengan ratarata pencapaian mereka sebelumnya, dan kepada masing-masing tim akan diberikan poin berdasarkan tingkat kemajuan yang diraih siswa dibandingkan hasil yang mereka capai sebelumnya. Poin ini kemudian dijumlahkan untuk memperoleh skor tim, dan tim yang berhasil memenuhi kriteria tertentu akan mendapatkan sertifikat atau penghargaan lainnya. Seluruh rangkaian kegiatan, termasuk presentasi yang disampaikan guru, praktik tim, dan kuis biasanya memerlukan waktu 3-5 periode kelas. Gagasan utama dari STAD adalah untuk memotivasi siswa supaya dapat saling mendukung dan membantu satu sama lain dalam menguasai kemampuan yang diajarkan oleh guru. Jika para siswa ingin agar timnya mendapatkan penghargaan tim, mereka harus membantu teman satu timnya untuk mempelajari materinya. Mereka harus mendukung teman, satu timnya untuk bisa melakukan yang terbaik, menunjukan norma bahwa belajar itu penting, berharga dan menyenangkan. Para siswa bekerja sama setelah guru menyampaikan materi pelajaran. Mereka boleh bekerja berpasangan dan membandingkan jawaban masing-masing, mendiskusikan setiap ketidaksesuaian, dan saling membantu satu sama lain jika ada yang salah dalam memahami. Mereka boleh mendiskusikannya dari pendekatan penyelesaian masalah, atau mereka juga boleh saling memberikan kuis mengenai objek yang sedang mereka pelajari. Mereka bekerja dengan teman satu timnya, menilai kekuatan dan kelemahan mereka untuk membantu mereka berhasil dalam kuis.

\section{Teams Games-Tournament (TGT)}

Metode ini menggunakan pelajaran yang sama yang disampaikan guru dan tim 
kerja yang sama seperti dalam STAD, tetapi menggantikan dengan kuis dengan turnamen mingguan, di mana siswa memainkan game akademik dengan anggota tim lain untuk menyumbangkan poin bagi skor timnya. Siswa memainkan game ini bersama tiga orang pada "meja turnamen" di mana ketiga peserta dalam satu meja turnamen ini adalah para siswa yang memilki rekor nilai matematika terakhir yang sama. Sebuah prosedur "menggeser kedudukan" membuat permainan ini cukup adil. Peraih rekor tertinggi dalama tiap meja turnamen akan mendapatkan 60 poin untuk timnya, tanpa menghiraukan dari meja mana ia mendapatkannya; ini berarti bahwa mereka yang berprestasi rendah (bermain dengan yang berprestasi tinggi) keduanya memiliki kesempatan yang sama untuk sukses. TGT memiliki banyak kesamaan dinamika dengan STAD, tetapi menambahkan dimensi kegembiraan yang diperoleh dari penggunaan permainan. Teman satu tim akan saling membantu dalam mempersiapkan diri untuk permainan dengan mempelajari lembar kegiatan dan menjelaskan masalah-masalah satu sama lain, tetapi sewaktu siswa sedang bermain dalam game temannnya tidak boleh membantu, memastikan telah terjadi tanggung jawab individual.

\section{Jigsaw II}

Jigsaw II adalah adalah adaptasi dari teknik teka-teki Elliot Aronson (1978). Dalam teknik ini siswa, bekerja dalam anggota kelompok yang sama, yaitu empat orang, dengan latar belakang yang berbeda seperti dalam $S T A D$ dan TGT. Para siswa ditugaskan untuk membaca bab, buku kecil, atau materi lain, biasanya bidang studi sosial, biografi, atau member materimateri yang bersifat penjelasan terperinci lainnya. Tiap anggota tim ditugaskan secara acak untuk menjadi "ahli" dalam aspek tertentu dari tugas membaca tersebut.

\section{Team Accelerated Intruction (TAI)}

Dalam TAI, para siswa memasuki sekuen individual berdasarkan tes penempatan dan kemudian melanjutkannya dengan tingkat kemampuan mereka sendiri. Secara umum, anggota kelompok bekerja pada unit pelajaran yang berbeda. Teman satu tim saling memeriksa hasil kerja masing-masing menggunakan lembar jawaban dan saling membantu dalam menyelesaikan berbagai masalah. Unit tes yang terakhir akan dilakukan tanpa bantuan teman satu tim dan skornya dihitung dengan monitor siswa. Tiap minggu, guru menjumlah angka dari tiap unit yang telah diselesaikan semua anggota tim dan memberikan sertifikat atau penghargaan tim lainnya untuk tim yang berhasil melampaui kriteria skor yang didasarkan pada angka tes terakhir yang telah dilakukan, dengan poin ekstra untuk lembar jawaban yang sempurna dan pekerjaan rumah yang telah diselesaikan. Karena para siswa bertanggung jawab untuk saling mengecek satu sama lain dan mengelola materi yang disampaikan, guru dapat menghabiskan waktu di dalam kelas penyampaian pelajaran kepada kelompok kecil siswa yang terdiri dari beberapa tim yang belajar pada tingkat yang sama dalam sekuen.

\section{Cooperatif Integrated Reading and Composition (CIRC)}

Merupakan program komprehensif untuk mengajarkan membaca dan menulis pada kelas sekolah dasar pada tingkat yang lebih tinggi dan juga pada sekolah menengah (Madden, Slavin, \& Steven, 1986). Dalam CIRC, guru menggunakan novel atau bahan bacaan yang berisi latihan soal dan cerita. Mereka mungkin menggunakan atau tidak menggunakan kelompok membaca, seperti dalam kelas membaca tradisional. Para siswa ditugaskan untuk berpasangan dalam tim mereka untuk belajar dalam serangkaian kegiatan yang bersifat kognitif, termasuk membacakan cerita satu sama lain, 
membuat prediksi mengenai bagaimana akhir dari sebuah cerita negarif, saling merangkum cerita satu sama lain, menulis tanggapan terhadap cerita, dan melatih pengucapan, penerimaan, dan kosa kata. Para siswa juga belajar dalam timnya untuk menguasai gagasan utama dan kemampuan komprehensif lainnya. Selama periode seni berbahasa, siswa terlibat dalam pelatihan penulisan, konsep penulisan, saling merevisi dan menyunting karya yang satu dengan lainnya, dan mempersiapkan pemuatan hasil kerja tim pada buku-buku kelas. Sedangkan, menurut Arends ada empat pendekatan pembelajaran kooperatif, yaitu: ${ }^{16}$

1) Student Teams Achievement Division (STAD). STAD dikembangkan oleh Robert Slavin dan rekan-rekan sejawatnya di Johns Hopkins University dan merupakan pendekatan cooperative learning yang paling sederhana dan paling mudah dipahami. Guru yang menggunakan STAD menyajikan informasi akademis baru kepada siswa, baik melalui verbal atau teks. Siswa di kelas tertentu dibagi menjadi beberapa kelompok, dengan wakil-wakil dari kedua gender, dari berbagai kelompok ras, dan dengan prestasi rendah, rata-rata dan tinggi. Anggota tim menggunakan worksheets atau alat lain untuk menguasai materi akademis dan kemudian saling membantu untuk mempelajari berbagai materi melalui tutoring, saling memberikan kuis, atau melaksanakan diskusi tim. Secara individual, siswa diberi kuis mingguan atau dua mingguan tentang berbagai materi akademis. Dalam mengerjakan kuis individual ini siswa dilarang bekerja sama dengan siswa lain.

2) Jigsaw. Jigsaw dikembangkan dan diuji oleh Elliot Aronson dan rekan-rekan sejawatnya. Menggunakan jigsaw,

\footnotetext{
${ }^{16}$ Arends Richard.I. ( 2008). Learning To Teach (Belajar Untuk Mengajar). Yogyakarta: Pustaka Belajar. Hlm.13.
}

siswa-siswa ditempatkan ke dalam timtim belajar heterogen beranggota lima sampai enam orang. Berbagai materi akademis disajikan kepada siswa dalam bentuk teks, dan setiap siswa bertanggung jawab untuk mempelajari satu porsi materinya. Para anggota dari tim-tim yang berbeda, tetapi membicarakan topik yang sama, bertemu untuk belajar dan saling membantu dalam mempelajari topik tersebut (biasanya disebut tim ahli). Setelah itu siswa kembali ke tim asalnya dan mengajarkan sesuatu yang telah mereka pelajari dalam tim ahli kepada anggota-anggota lain di timnya masing-masing.

3) Group Investigation (GI). Group Investigation (GI) yang aslinya dirancang oleh Herbert Thelen, yang lebih mutakhir pedekatan ini diperluas dan disempurnalan oleh Sharan dan rekan-rekannya di Tel Aviv University. GI merupakan pendekatan cooperative learning yang paling kompleks dan paling sulit diimplementasikan. GI melibatkan siswa dalam merencanakan topik-topik yang akan dipelajari dan bagaimana cara menjalankan investigasinya.

4) Pendekatan Struktural. Pendekatan cooperative learning lainnya dikembangkan selama dekade lalu, terutama oleh Spencer Kagan. Pendekatan struktural menekankan penggunaan struktur tertentu yang dirancang untuk mempengaruhi pola interaksi siswa. Struktur Kagan mengharuskan siswa untuk bekerja secara independen di kelompokkelompok kecil dan ditandai oleh reward kooperatif dan bukan reward individual.

Arends memberikan dua contoh model pembelajaran kooperatif struktural $^{17}$ yaitu;

${ }^{17}$ Arends Richard.I. (2008). Learning To Teach (Belajar Untuk Mengajar). Yogyakarta: Pustaka Belajar. HIm.15. 
a) Think-Pair-Share (TPS). Pendekatan ini menantang asumsi bahwa semua resitasi atau diskusi perlu dilakukan dalam setting seluruh kelompok, dan memilki prosedur-prosedur built-in untuk memberikan lebih banyak waktu kepada siswa untuk berfikir, untuk merespons, dan untuk saling membantu.

b) Numbered Heads Together (NHT). Merupakan pendekatan yang dikembangkan oleh Spencer Kagan untuk melibatkan lebih banyak siswa dalam review berbagai materi yang dibahas dalam sebuah pelajaran dan untuk memeriksa pemahaman mereka tentang isi pelajaran itu.

Dari beberapa pengertian di atas, maka dapat disimpulkan bahwa model pembelajaran kooperatif merupakan upaya dalam rangka mengaktifkan siswa dengan cara bekerja dalam kelompok yang berbeda latar belakang, saling berbagi pengetahuan, mengungkapkan pendapat untuk menyelesaikan masalah atau tugas yang telah diberikan guru secara bersama-sama.

\section{F. Model Pembelajaran Kooperatif Perspektif al-Qur'an}

Dalam al-Qur'an banyak sekali ayat yang berhubungan dengan pembelajaran dan metode pembelajaran. Walaupun AlQuran tidak secara langsung mendefinisikan pembelajaran kooperatif, tetapi jelas prinsip-prinsip dan unsur-unsur pembelajaran kooperatif banyak diisyaratkan dalam al-Quran, antara lain:

\section{Saling Ketergantungan yang Bersifat Positif Antara Siswa}

Dalam belajar kooperatif siswa merasa bahwa mereka sedang bekerja sama untuk mencapai satu tujuan dan terikat satu sama lain. Ini sesuai dengan ajaran AlQuran yang memerintahkan untuk selalu saling tolong-menolong dalam kebaikan. Sebagaimana yang dijelaskan dalam alQur' an surat al-Maidah ayat 2, Allah SWT berfirman:

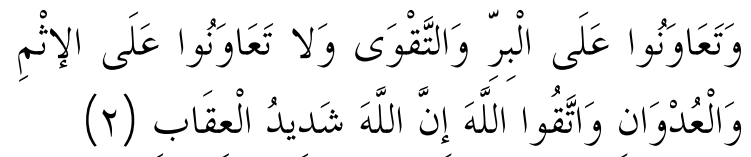

Dan tolong-menolonglah kamu dalam (mengerjakan) kebajikan dan takwa, dan jangan tolong-menolong dalam berbuat dosa dan pelanggaran. Dan bertakwalah kamu kepada Allah, sesungguhnya Allah amat berat siksa-Nya. (Q.S. al-Maidah[5]: 2)

Dari ayat tersebut dapat kita simpulkan bahwa Allah menghendaki umat-Nya untuk saling tolong-menolong dan bekerja sama dalam hal kebaikan. Demikian juga dalam hal belajar yang merupakan suatu proses untuk memperoleh perubahan tingkah laku sebagai hasil dari pengalaman dalam interaksi dengan lingkungan. Melalui pembelajaran secara berkelompok diharapkan siswa dapat memperoleh suatu pengalaman yang baru melalui interaksi dengan orang lain dalam kelompoknya.

\section{Tanggung Jawab Individual}

Tanggung jawab individual dalam belajar kelompok dapat berupa tanggung jawab siswa dalam hal membantu siswa yang membutuhkan bantuan dan siswa tidak dapat hanya sekedar "membonceng" pada hasil kerja teman sekelompoknya. Mengenai hal ini Allah berfirman:

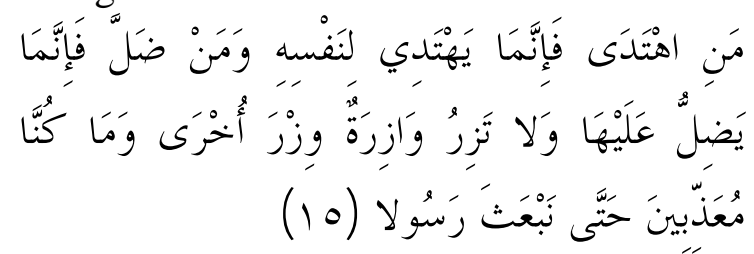

Barangsiapa yang berbuat sesuai dengan hidayah (Allah), maka sesungguhnya dia berbuat itu untuk (keselamatan) dirinya sendiri; dan barangsiapa yang sesat maka sesungguhnya dia tersesat bagi (kerugian) dirinya sendiri. Dan seorang yang berdosa tidak dapat memikul dosa orang lain, dan Kami tidak akan mengazab sebelum Kami mengutus seorang rasul. (QS. Al-Isra' [17]: 15) 
Dalam tafsirnya, Qurasih Syihab menjelaskan ayat ini bahwa barangsiapa mengikuti jalan yang benar, maka sesungguhnya manfaatnya akan kembali kepada dirinya sendiri. Dan barangsiapa keluar dari jalan kebenaran, maka dosa ketersesatannya itu kembali kepada dirinya pula. Seorang manusia yang berdosa tidak akan menanggung dosa manusia lainnya. Tidaklah benar bagi Kami untuk menyiksa seseorang karena perbuatan buruknya, padahal Kami belum mengutus kepadanya seorang utusan Kami yang menunjukkan kepada kebenaran dan mencegah kebatilan.

\section{Keterampilan Interpersonal dan Kelompok Kecil}

Dalam belajar kooperatif, selain dituntut untuk mempelajari materi yang diberikan seorang siswa dituntut untuk belajar bagaimana berinteraksi dengan siswa lain dalam kelompoknya. Bagaimana siswa bersikap sebagai anggota kelompok dan menyampaikan ide dalam kelompok akan menuntut keterampilan khusus.

Ketergantungan manusia terhadap sesamanya atau berinterkasi rupanya juga menjadi salah satu tuntunan dalam ajaran Islam dimana sebenarnya manusia diciptakan oleh Allah di muka bumi ini tiada lain untuk dapat saling mengenal dan tolong menolong. Hal tersebut sesuai dengan firman Allah SWT sebagai berikut:

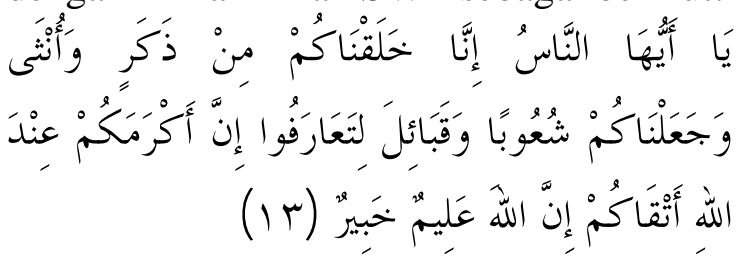

Hai manusia, sesungguhnya Kami menciptakan kamu dari seorang laki-laki dan seorang perempuan dan menjadikan kamu berbangsa-bangsa dan bersuku-suku supaya kamu saling kenal-mengenal. Sesungguhnya orang yang paling mulia diantara kamu disisi Allah ialah orang yang paling takwa diantara kamu. Sesungguhnya Allah Maha Mengetahui lagi Maha Mengenal. (Q.S. al-Hujarat [49]: 13)

Dalam hal kerjasama, sebenarnya Islam juga memerintahkan umatnya untuk saling tolong-menolong dan bekerjasama dalam kebaikan dan manfaat. Lebih lagi terhadap sesama umat Islam. Bahkan Islam mengibaratkan persaudaraan dan pertalian sesama muslim itu seperti satu bangunan, dimana struktur dan unsur bangunan itu saling membutuhkan dan melengkapi, sehingga menjadi sebuah bangunan yang kokoh, kuat dan bermanfaat lebih.

\section{Proses Kelompok}

Belajar kooperatif tidak akan berlangsung tanpa proses kelompok. Proses kelompok terjadi jika anggota kelompok mendiskusikan bagaimana mereka akan mencapai tujuan dengan baik dan membuat hubungan kerja yang baik. Mangenai hal ini Al-Quran menjalaskan dalam QS. As-Shaf [61]: 4:

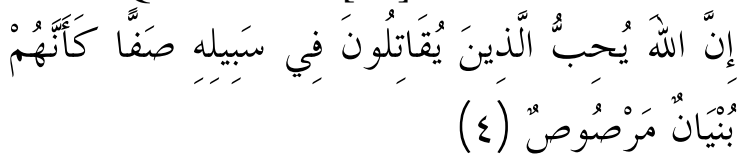

Sesungguhnya Allah menyukai orang yang berperang dijalan-Nya dalam barisan yang teratur seakan-akan mereka seperti suatu bangunan yang tersusun kokoh.

Dalam tafsirannya Ayat ini merupakan dorongan dari Allah Subhaanahu wa Ta'aala kepada hambahamba-Nya untuk berjihad di jalan-Nya dan mengajarkan kepada mereka bagaimana yang seharusnya mereka lakukan, dan bahwa sepatutnya mereka berbaris secara rapi dalam jihad tanpa ada celah dalam barisan, dimana barisan mereka tersusun rapi dan tertib yang dengannya dicapai kesamaan antara para mujahid, saling bantu-membantu, membuat musuh gentar dan membuat semangat. Oleh karena itulah, Nabi shallallahu 'alaihi wa sallam apabila berperang menyusun barisan para sahabatnya dan merapikan posisi-posisi mereka sehingga tidak terjadi 
bersandarnya sebagian mereka kepada yang lain, bahkan masing-masing kelompok fokus di tempatnya dan mengerjakan tugasnya, sehingga dengan cara seperti ini sempurnalah amal dan tercapailah kesempurnaan.

Dalam konteks pembelajaran kooperatif proses kelompok terjadi jika anggota kelompok mendiskusikan secara kompak bagaimana mereka akan mencapai tujuan dengan baik dan membuat hubungan kerja sama yang baik.

\section{G. Kesimpulan}

Pembelajaran kooperatif dapat menjadi salah satu alternatif mengingat banyak pendapat yang menyatakan bahwa pembelajaran aktif termasuk kooperatif mampu meningkatkan efektivitas pembelajaran. Pembelajaran kooperatif mengutamakan kerjasama antar siswa untuk mencapai tujuan pembelajaran. Menggunakan pembelajaran kooperatif dapat mengubah peran guru, dari yang berpusat pada gurunya ke pengelolaan siswa dalam kelompok-kelompok kecil. Model pembelajaran kooperatif dapat digunakan untuk mengajarkan materi yang kompleks, dan yang lebih penting lagi, dapat membantu guru untuk mencapai tujuan pembelajaran yang berdimensi sosial dan hubungan antar manusia. Pembelajaran kooperatif memiliki manfaat atau kelebihan yang sangat besar dalam memberikan kesempatan kepada siswa untuk lebih mengembangkan kemampuannya. Hal ini dikarenakan dalam kegiatan pembelajaran kooperatif, siswa dituntut untuk aktif dalam belajar melalui kegiatan kerjasama dalam kelompok.

Al-Qur'an adalah kalam Allah yang menjadi sumber segala hukum dan menjadi pedoman dalam kehidupan, termasuk membahas tentang pembelajaran. Dalam al-Qur'an banyak sekali ayat yang berhubungan dengan pembelajaran dan metode pembelajaran. Walaupun Al-Quran tidak secara langsung mendefinisikan pembelajaran kooperatif, tetapi jelas prinsip-prinsip dan unsur-unsur pembelajaran kooperatif banyak diisyaratkan dalam al-Quran.

\section{DAFTAR PUSTAKA}

Agus Suprijono. (2014). Cooperative Learning: Teori dan Aplikasi PAIKEM. Yogyakarta: Pustaka Pelajar.

Anita Lie. (2003).Cooperative Learning: Mempraktekkan Coopeartif Learning di Ruang-ruang Kelas. Jakarta: PT Grasindo.

Arends Richard. I. (2008). Learning To Teach (Belajar Untuk Mengajar). Yogyakarta: Pustaka Belajar.

Nur Asma. (2006). Pendekatan Pembelajaran Kooperatif. Jakarta: Departemen Pendidikan Nasional Direktorat Jenderal Pendidikan Tinggi Direktorat Ketenagaan.

Peraturan Menteri Pendidikan Dan Kebudayaan Republik Indonesia, Nomor 49 Tahun 2014 Tentang Standar Nasional Pendidikan Tinggi, Pasal 14.

Rusman. (2012). Model-model Pembelajaran. Jakarta: PT. Raja Grafindo Persada.

Slavin, Robert. E. (2009). Cooperative Learning Teori, Riset, \& Praktik. Bandung: Nusa Media.

Trianto. (2007). Model-model Pembelajaran Inovatif Berorientasi Konstruktivistik. Jakarta: Prestasi Pustaka. 